Report No. 27

Fracture Mechanics

Evaluation of Railroad

Tank Cars Containing Circumferential Cracks

\section{George E. Hicho \\ Akram Zahoor \\ Richard J. Fields \\ Roland deWit}

U.S. DEPARTMENT OF COMMERCE Technology Administration

National Institute of Standards

and Technology

Gaithersburg, MD 20899

$-Q C$ 


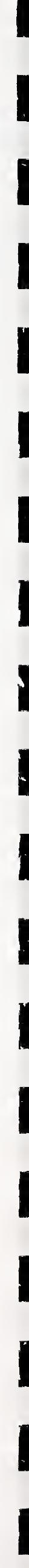


Report No. 27

\title{
Fracture Mechanics Evaluation of Railroad Tank Cars Containing Circumferential Cracks
}

\author{
George E. Hicho \\ Akram Zahoor \\ Richard J. Fields \\ Roland deWit \\ U.S. DEPARTMENT OF COMMERCE \\ Technology Administration \\ National Institute of Standards \\ and Technology \\ Gaithersburg, MD 20899
}

April 1993

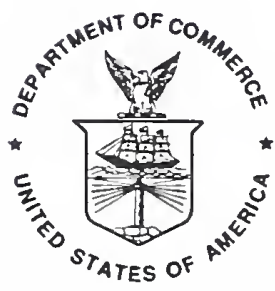

U.S. DEPARTMENT OF COMMERCE Ronald H. Brown, Secretary 


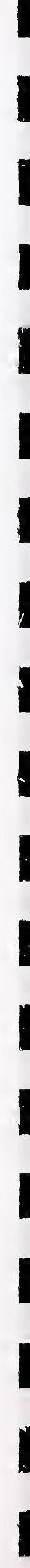


George E. Hicho, Akram Zahoor ${ }^{1}$, Richard J. Fields, and Roland deWit

Mechanical Properties and Performance Group Materials Science and Engineering Laboratory National Institute of Standards and Technology Metallurgy Division

Gaithersburg, MD 20899

\section{ABSTRACT}

Fracture mechanics analyses using the J-integral as fracture parameter were performed on railroad tank cars made from normalized AAR TCl28 grade B steel. Circumferential throughwall cracks in the tank car shell region were postulated to determine the critical crack size for axial tension loadings anticipated in service. Five loading cases were considered. These were: (1) coupler impact, (2) test pressure, (3) start-to-discharge pressure, (4) bursting pressure, and (5) vapor tight minimum pressure. The analyses were performed for two service temperatures, $-40^{\circ} \mathrm{C}\left(-40^{\circ} \mathrm{F}\right)$ and $22^{\circ} \mathrm{C}\left(72^{\circ} \mathrm{F}\right)$. The bounding critical crack length is determined to be approximately 30 times the tank car shell wall thickness for the start-to-discharge event. The critical crack lengths for the coupler impact force are approximately 1.7 times larger than those for the discharge pressure. The critical crack length is determined to be the largest for the impact force case. The results also show that even at burst pressure, small throughwall cracks (four times tank shell thickness) can be tolerated.

\section{INTRODUCTION}

Since January 1, 1989, the normalized AAR TCl28 grade B steel is to be used for railroad tank cars that may carry hazardous commodities. Prior to this date, the TC128 grade B steel used in tank cars was normally supplied in the as rolled condition. Previous research $(1,2,3$, and 4) showed that the mechanical properties, in particular the impact strength at low test temperatures for the steel in the as rolled condition was markedly lower than normalized TC128 grade $B$ steel. Fracture toughness tests conducted on these steels showed that the normalized steel resists crack initiation better than the as rolled steel. As part of our present program with the Federal Railroad Administration, research was initiated using data generated at NIST, to assess the structural integrity of the tank car shell containing postulated circumferential throughwall cracks under axial tension loading. The latest fracture mechanics analysis methods were

1 Consultant, Zenith Corporation, Rockville, MD 20855 
used to determine the critical crack size for service conditions at $-40{ }^{\circ} \mathrm{C}$. $\left(-40{ }^{\circ} \mathrm{F}\right)$ and $22^{\circ} \mathrm{C}\left(72{ }^{\circ} \mathrm{F}\right)$. The fracture mechanics methods and analyses previously used for the tank car evaluation were based on linear elastic fracture mechanics (LEFM). Further, the solutions used were for the simplified case of a flaw in a flat plate. Consequently, the effects of tank shell geometry and flaw orientation were ignored in the analysis. The analyses performed in this report use appropriate J-integral elastic-plastic fracture mechanics solutions for the tank car geometry, thus allowing accurate evaluation. The J based analyses are superior to those based on LEFM concepts because it accounts for crack tip plasticity consistent with the material stress-strain curve and allows assessment of the stability of crack extension. The report also discusses the American Association of Railroads (AAR) analysis method previously used for assessing tank car structural integrity and compares with the latest technology used in this report. Areas for improvements are discussed.

\section{ELASTIC-PLASTIC FRACTURE MECHANICS METHOD}

The fracture analysis method used in this report is based on the elastic-plastic $\mathrm{J}$ integral and associated tearing modulus crack stability criterion. Ductile fracture analysis consists of two components: crack driving potential ( $\mathrm{J}$ ) and the material's resistance to crack extension. The crack driving potential is computed from a formula that depends on the applied load, component geometry, service temperature, and stress-strain properties of the material. The crack extension resistance is measured from laboratory specimens. This latter component is characterized by the J-resistance curve of the material. The crack driving potential is then compared to the material resistance to assess the component's fitness for service.

The Crack Driving Potential (J):

The fracture mechanics evaluation of the railroad tank car shell was performed using the $\mathrm{J}$ integral elastic-plastic fracture parameter. In general, the Jintegral solution is expressed as (5):

$$
\mathrm{J}=\mathrm{Je}+\mathrm{Jp}
$$

The first term on the right hand side of Eq. (1) is the elastic J modified for small scale yielding. The elastic $J$ can be computed from the mode I stress intensity factor, $\mathrm{K}_{1}$, as $\mathrm{K}_{\mathrm{I}}{ }^{2} / \mathrm{E}$ where $\mathrm{E}$ is the elastic modulus of the material. The second term is the plastic component of the J-integral, which depends upon crack size, component geometry, and plastic characteristics of the stress strain curve.

Limited elastic and elastic-plastic $J$ solutions for throughwall cracks in cylindrical geometries were developed originally in Refs. 6, 7. These solutions were later expanded to cover a wide range of crack sizes and are given in Refs. 5, 8. In general, solutions for shell geometries with a large radius-tothickness ratio ( $R / t$ greater than 20) are available only for linear elastic fracture analysis, and these are limited to a few crack lengths, Refs. 9-11. 
Material Fracture Resistance. The J-Resistance Curve:

The J-resistance curve is most commonly generated from compact tension, $\mathrm{C}(\mathrm{T})$, specimens following the procedures set forth in ASTM El 152-87 (12). The specimen size is selected so that it either has the same thickness as the component thickness or has a thickness that would produce a conservative estimate of the material's resistance to crack extension. The direction of crack extension in the specimen is selected to match that of the flaw in the application.

While J-R curves can be generated for the appropriate direction of crack extension in the application, the data are usually limited to small crack extension due to the specimen size limitation. A standard ASTM compact tension, IT C(T), specimen produces only .25 to $.51 \mathrm{~cm}$ ( 0.1 to 0.2 inch) of valid crack extension. When it is not possible to fabricate a standard thickness specimen due to smaller component thickness, it is preferred that the specimen has approximately the same thickness as in the application.

Stability Limit. The J-Integral Tearing Modulus:

The analyses performed in this report are based on the $\mathrm{J}$-integral tearing modulus $(\mathrm{J}-\mathrm{T})$ method. The analysis method compares the crack driving potential (J) to the material resistance ( $J-R$ curve). During stable crack growth these two parameters are equal until a stability limit is reached. It may be shown that this limit is given by tearing modulus related to the slope of the J-resistance curve.

The J-T analysis used here was developed in 1977 (13). Initially, it was used to demonstrate the concept of ductile tearing instability to specimen geometries, which included single edge notched bend, $C(T)$, and center-cracked tension specimens (14). This analysis was later applied to cracked pipes and the analys is was based on perfectly plastic assumption. Subsequent work (15-19) removed this assumption and developed the $J$ and $T$ solutions for throughwall cracks, part throughwall cracks, and compound cracks under bending, axial tension, or torsional loading.

The J-T procedure for determining the load at incipient crack instability is described below. Suppose that the maximum bending moment needs to be computed for a specified circumferential throughwall crack length in a cylinder. The first step in performing this analysis is to determine the applied J-integral as a function of the applied loads for the specified cylinder geometry and crack size. The applied $J$ is calculated as a function of bending moment using Ref. 5 solution as shown schematically in Figure la. Next, applied J also is computed as a function of tearing modulus (using Ref. 5 solutions) for the specified crack length and a range of bending moments. The applied $J$ and $T$ pairs computed at each bending moment are then plotted to establish the applied $J-T$ line shown schematically in Figure $1 b$.

A J-T curve representing the material crack extension also is determined and plotted on Figure $\mathrm{lb}$. The naterial J-T curve is developed from an experimental $\mathrm{J}$ versus crack extension ( $J-R$ ) curve, which can be obtained from compact tension specimens or specimens with same geometry as the component. The value of 
material $\mathrm{T}$ at any specified value of $\mathrm{J}$ is determined from the slope of the. $\mathrm{J}-\mathrm{R}$ curve as:

$$
T=(\Delta J / \Delta a) \cdot\left(E / \sigma_{f}^{2}\right)
$$

where $E$ and $\sigma_{f}$ are the elastic modulus and material flow stress, respectively. The flow stress is a reference quantity usually defined as one-half the sum of yield and ultimate tensile strengths. The $\Delta \mathrm{J} / \Delta \mathrm{a}$ is the slope of the J-R curve at any specified value of $\mathrm{J}$.

The intersection of the applied and material J-T curves illustrated in Figure 1 (b) defines the $\mathrm{J}$ and $\mathrm{T}$ values corresponding to crack instability. The maximum bending moment is determined by entering Figure la with the $J$ at crack instability from Figure $1 b$ and determining the corresponding value of bending moment. This procedure is repeated using current crack length (original crack length plus calculated crack extension), and a revised bending moment is obtained.

A similar procedure can be used to determine the allowable crack length for any specified load when Figure $1 \mathrm{la}$ is replaced by a plot of $\mathrm{J}$ versus crack length for the specified load. The procedure is the same for part-throughwall cracks, any other flaw geometry, or loading type. Further details can be found in Ductile Fracture Handbook, Ref. 5, which also contains a sample problem and the step-bystep solution.

\section{ASSESSMENT OF FRACTURE ANALYSES METHODS}

\section{AAR Fracture Analyses Method:}

This section describes the fracture analysis method developed by Pellini for the Association of American Railroads (AAR) $(20,21)$. The method is based on LEFM principles and defines procedures for both the crack initiation and crack arrest analysis. The method and procedures have been defined so that, with certain assumptions, it can be used as a design reference graph. It was developed for application to low and intermediate steels having less than $482 \mathrm{MPa}$ (70 ksi) yield strength.

The AAR method requires the following basic information to determine the critical load or crack size.

- $K_{1}$ curve for the dynamic loading of interest, e.g., $K_{I d}$ curve for the material

- NDT temperature or NDT temperature band for the material

- $K_{I c}$ versus temperature fur the material

- Material tensile properties

- Stress intensity factor solution for the flaw geometry 
The procedure for developing the crack arrest diagram is described below. The procedure requires definition of two points: L and YC. These are defined on the $\mathrm{K}_{\mathrm{Id}}$ curve. Figure 2 (21) shows the $\mathrm{K}_{\mathrm{Id}}$ curve, which is a plot of $\mathrm{K}_{\mathrm{Id}}$ versus temperature relative to NDT. The abscissa of this figure can be expressed alternately as temperature with NDT point marked to distinguish brittle to ductile transition. The relative temperature scale is preferred for graphical methods. The NDT temperature is established by the drop-weight test. The test is a fixed crack size test and is conducted by dynamically loading the specimen to yield stress level. The $\mathrm{K}_{\mathrm{Id}}$ curve has been widely used in industry, and ASME Code procedures for reactor vessels are based on such a curve. The point $\mathrm{L}$ is defined by the plane strain limit for specified section thickness, and represents the largest value of $\mathrm{K}_{\mathrm{Id}}$ allowed in a valid test. The point $\mathrm{L}$ takes on higher values for higher section thickness. It defines the point beyond which LEFM methods do not apply because elastic-plastic fracture regime begins from this point to higher $\mathrm{K}_{\mathrm{ld}}$ values.

The $\mathrm{K}_{\mathrm{Id}}$ value at point $\mathrm{L}$ is calculated from the following formula:

$$
K_{\mathrm{Id}}=\left(\sigma_{y d}\right) \cdot(B / 2.5)^{1 / 2}
$$

where $B$ is the section thickness, $\sigma_{y d}$ is estimated to be $\sigma_{y}+158$ in MPa units (23 in ksi units), where $\sigma_{y}$ is 0.2 percent offset yield strength (20).

The YC point refers to the yield criterion value of $K_{I d}$ for specified section thickness. It signifies a condition of crack arrest for applied stress equal to yield stress. The YC point is relevant to structures subjected to accidental overloading. This point is clearly well into the elastic-plastic fracture region, and an elastic-plastic fracture parameter should be used to define the YC point. In the AAR method (20), this point is defined by assuming LEFM behavior:

$$
\mathrm{K}_{\mathrm{Id}}=\left(\sigma_{\mathrm{yd}}\right) \cdot(\mathrm{B})^{1 / 2}
$$

where $B$ and $\sigma_{y d}$ have the same definition as defined for Eq. (3). An examination of Eqs. (3) and (4) indicates that the YC and $L$ values are related to each other by a constant factor $(\sqrt{2.5})$ regardless of the section thickness, NDT temperature, and material properties.

Figure 3 (20) shows the L-YC lines on a plot of applied stress to yield stress ratio $\left(\sigma / \sigma_{y}\right)$ versus temperature relative to NDT. The $K_{1 d}$ value at $L$ and YC points is calculated by using Eqs. (3) and (4) for specified section thickness. These values are then used with the $K_{I d}$ curve of Figure 2, giving the reference temperatures for the $\mathrm{L}$ and $\mathrm{YC}$ points. These points are shown on Figure 3 , where the value $\sigma / \sigma_{y}$ for the $L$ point is set at 0.2 based on the experimental data. This is an approximation since there is some variation in this value for different materials and section thickness. The L-YC curve is assumed as straight line, although a curve can be developed using LEFM or elastic-plastic fracture mechanics (EPFM) methods. The L-YC lines of Figure 3 form the basis for the 
crack arrest diagram. The crack arrest line for a $2.54 \mathrm{~cm}$ (1-inch) thick section is shown in Figure 4 (21). It is assumed that this curve applies also to section thickness less than $2.54 \mathrm{~cm}$, but the justification is lacking.

\section{Crack Initiation Diagram:}

The crack initiation curves are developed using fracture toughness at the initiation of crack extension, $\mathrm{K}_{\mathrm{lc}}$ as the basis. It is more appropriate to use $\mathrm{K}_{c}$ instead of $\mathrm{K}_{\mathrm{Ic}}$ for thinner sections. The $\mathrm{K}_{\mathrm{l}}$ calculations are performed for a specified flaw size with applied load (or stress) as a parameter. The calculated $K_{1}$ value is then compared with $K_{l c}$ to determine the load (or stress) at initiation of crack extension. Such a calculation is repeated for all possible combinations of flaw size. The result is a series of curves for $\sigma / \sigma_{y}$ versus temperature with crack depth as a parameter. Figure 4 (21) illustrates two sets of initiation curves for quasistatic and dynamic loading cases. A part-throughwall crack is assumed in Figure 4. A separate set of curves should be developed for another flaw geometry, e.g., throughwall crack. It should be noted that a set of such curves can be developed only for the specified $K_{I c}$ at a specific temperature.

\section{Discussion:}

The fracture mechanics solution used in the development of crack initiation diagram is based on a flaw in a flat plate $(20,21)$. Such a solution ignores consideration of tank car cylindrical geometry. Further, it does not make a distinction whether the flar: is oriented in the circumferential or axial direction. For an accurate analysis, solution for part-throughwall flaw in a cylindrical geometry should be used. Further, separate solutions for axial and circumferential flaws should be used. Finally, where appropriate, an elasticplastic fracture parameter, e.g., J-integral parameter, should be used.

The YC point on the crack arrest diagram is clearly well into the elastic-plastic fracture region. Consequently, an elastic-plastic fracture parameter should be used to define this point. Further, the L-YC curve is assumed as a straight line. Accurate L-YC curves should be developed using EPFM method.

A large number of studies have shown that the use of $k_{1}$ solution and $k_{l c}$ instead of $\mathrm{K}_{c}$ can lead to very conservative analysis, particularly when ductile fracture is expected. Reference 22, among others, discussed the advantages of an EPFM analysis. It is well known that fracture may not occur at the initiation of crack extension when toughness increases appreciably with crack extension. Therefore, improvements can be made to initiation curves by using resistance curves in fracture analysis. A resistance curve $\left(K_{1}-\Delta a\right.$ or $\left.J-\Delta a\right)$ based analysis can take credit for additional material resistance to crack extension.

The $\mathrm{J}$ - integral tearing modulus ( $\mathrm{J}-\mathrm{T}$ ) method, which applies to both the LEFM and EPFM fracture regimes, has been used to determine the load at which unstable crack extension would occur. The J-T method is well suited to examine the possibility of fracture at any point at and beyond initiation of crack extension.

The analyses performed in the Evaluation of Railroad Tank Cars section illustrate how an EPFM method can be used to develop critical crack size curves. These 
curves would replace the initiation curves of Figure 4. The section XI of the ASME Code (23) contains analysis methods, procedures, and easy-to-use flaw evaluation tables for carbon steel and stainless steel piping materials and associated weldments Refs. 24-29. The flaw evaluation procedures for carbon steel piping Refs. 27, 28, 29 include screening criteria that define whether a LEFM or an EPFM analysis is appropriate before using flaw evaluation tables or performing application specific analysis. The basic elements of these procedures are now being considered by the petrochemical industry. The basic elements of ASME procedures can be developed further for application to railroad tank cars.

\section{EVALUATION OF RAILROAD TANK CARS}

The analyses performed in this work are based on the J-integral elastic-plastic fracture parameter. The $\mathrm{J}$ based analyses are superior to those based on linear elastic fracture mechanics concept because it accounts for crack tip plasticity consistent with the material stress-strain curve and allows assessment of the stability of crack extension. The fracture mechanics methods and analyses previously used for the tank car evaluation were based on LEFM. Further, the solutions used for the tank car were for the simplified case of a flaw in a flat plate. Consequently, the effects of tank shell geometry were ignored in the analyses. The analyses performed in this section use appropriate J-integral elastic-plastic solutions for the tank car geometry, thus allowing accurate evaluation.

\section{Circumferential Throughwall Crack Under Axial Tension:}

\section{Stress Intensity Factor Solution:}

The mode I stress intensity factor for the tank car shell geometry with radius-to thickness ratio $(\mathrm{R} / \mathrm{t})$ of 100 is given below (30):

$$
K_{I}=\left(\sigma_{t}\right) \cdot(\pi R \theta)^{1 / 2} \cdot F_{t}(\theta)
$$

where: $\quad \sigma_{t}=P /(2 \pi R t) \quad$ and

$$
F_{t}(\theta)=1+4.93 \cdot\left[5.3303 \cdot(\theta / \pi)^{1.5}+18.773 \cdot(\theta / \pi)^{4.24}\right]
$$

$P$ is the applied axial load; $R, t$, and $\theta$ are the shell mean radius, wall thickness, and crack half-angle, respectively. Figure 5 shows the through wall crack geometry. This solution applies to $0<\theta / \pi \leq 0.15$ and $R / t=100$. The solution has the following accuracy: (i) better than $2 \%$ for $\theta / \pi \leq 0.05$ as compared to the results in Ref. 9, and (ii), the solution is increasingly conservative for $\theta / \pi>0.05$.

\section{J-Integral Solution:}

The $\mathrm{J}$-integral solution for $\mathrm{R} / \mathrm{t}=100$ is given below (30).

$$
J=(1 / E) \sigma_{t}{ }^{2}\left(\pi R \theta_{\Theta}\right) F_{t}{ }^{2}\left(\theta_{\Theta}\right)+\alpha \sigma_{0} \epsilon_{0} R(\pi-\theta) \cdot H_{1} \cdot\left(B_{0}(\theta)\right)^{m} \cdot\left(P / P_{0}(\theta)\right)^{n+1}
$$


where:

$$
\begin{aligned}
& \theta_{\Theta}=\theta\left[1+\left(0.5 \mathrm{~F}_{\mathrm{t}}(\theta)^{2}\right) \cdot\{(\mathrm{n}-1) /(\mathrm{n}+1)\} \cdot\left(\sigma_{\mathrm{t}} / \sigma_{0}\right)^{2} /\left(1+\left(\mathrm{P} / \mathrm{P}_{\mathrm{o}}(\theta)\right)^{2}\right\}\right] \\
& \mathrm{P}_{0}(\theta)=2 \sigma_{0} \operatorname{Rt}[\pi-\theta-2 \arcsin (0.5 \sin \theta)] \\
& \mathrm{B}_{0}(\theta)=\left[1+4.93\left\{5.3303(\theta / \pi)^{1.5}+18.773(\theta / \pi)^{4.24}\right\}\right] / \\
& \quad\left[1+1.1495\left\{5.3303(\theta / \pi)^{1.5}+18.773(\theta / \pi)^{4.24}\right\}\right] \\
& \mathrm{m}=(\mathrm{n})^{0.5}
\end{aligned}
$$

This result has the correct elastic limit, shown in Eq. (5), because $\theta_{\Theta}=\theta$ and $\alpha=0$, when $n=1$. $H_{1}$ depends upon $\theta / \pi, n$, and $R / t$. In the above solution, $H_{1}$ is to be used for the $R / t=20$. The solution assumes plane stress crack-tip condition; the plane stress condition is appropriate for the tank car shell geometry. The $\mathrm{R}, t$, and $\theta$ are the tank mean radius, wall thickness, and crack half-angle, respectively. The $\alpha, \sigma_{0}, \epsilon_{0}$, and $n$ are constants in the RambergOsgood stress-strain relation:

$$
\epsilon / \epsilon_{0}=\sigma / \sigma_{0}+\alpha\left(\sigma / \sigma_{0}\right)^{n}
$$

The $\sigma_{0}$ and $\epsilon_{0}$ are the reference stress and reference strain, respectively, and are related to each other by the relation $\sigma_{0} / \epsilon_{0}=E$. The $\sigma_{0}$ is 0.2 percent offset yield strength and $\mathrm{E}$ is the elastic modulus. The $\mathrm{H}_{1}$ values are tabulated in $\operatorname{Ref}$. 5 for $R / t=20$ and $r=1,2,3,5$, and 7 . Linear interpolation between specified values of $\theta / \pi$ and $n$ in tables is permitted. The $J$ solution given above is applicable to $\mathrm{n} \leq 10$.

\section{Loading Cases:}

Several loading cases were considered for the determination of critical crack size. These included loads anticipated or implied in the service, test, certain accident condition, and design condition for the railroad tank car. These loadings are defined in the Manual of Standards \& Recommended Practices (31). The loading categories considered in this report are: (1) impact force, (2) test procedure, (3) start-to-discharge pressure, (4) burst pressure, and (5) vapor tight minimum pressure. Table 1 shows the loads used for each category. These values were obtained from reference (31). Except for the impact force case, the load was defined in terms of the internal pressure. The axial load was calculated using $\pi R^{2} p$ where $p$ is the internal pressure in the tank car. The $R$ and $t$ values used were $140 \mathrm{~cm}$ (55 inch) and $1.43 \mathrm{~cm}(0.5625$ inch), respectively.

Fracture Mechanics Analyses:

The fracture mechanics analyses performed in this report are based on the $\mathrm{J}$ integral tearing modulus ( $\mathrm{J}-\mathrm{T}$ ) method. This approach was described previously. The method compares the crack driving potential $(\mathrm{J})$ to the material's resistance $(\mathrm{J}-\mathrm{R})$ curve. If the calculated $\mathrm{J}$ value is smaller than the material $\mathrm{J}$ value at the initiation of crack extension $J_{I}$ value, then crack extension is implied. However, this crack extension can occur in a stable or unstable manner. To 
determine this possibility, the rate increase in the calculated (applied) I is compared to the rate increase in the material's resistance to crack extension at the calculated $J$ value. This quantity when normalized with certain combinations of material properties is called the tearing modulus, as discussed in a previous section. If the calculated value is greater than that for the material, the crack is predicted to extend in an unstable manner causing fracture of the tank car.

The J-T method is applied to situations where ductile tearing is anticipated. However, when ductile crack extension is not anticipated due to the material behavior at the temperature of evaluation, the method is still applicable. Here only the $J$ values are compared with $J_{1}$ to determine the critical crack size for specified load or critical load for the specified crack size.

The fracture mechanics analyses were performed for postulated circumferential throughwall cracks in the railroad tank car shell region. The mean radius and the wall thickness of the tank car used were $140 \mathrm{~cm}$ and $1.43 \mathrm{~cm}$ (55.0 inch and 0.56 inch), respectively. The analyses were performed for the AAR TCl28 grade $\mathrm{B}$ normalized material at service temperatures of $-40{ }^{\circ} \mathrm{C}$ and $22{ }^{\circ} \mathrm{C}$. Only the initiation $J$ values were available at these temperatures. Therefore, the critical crack size calculations were performed for applied $J$ values equal to the material's initiation $\left(J_{l}\right)$ value.

The material $\mathrm{J}$ values at $-40{ }^{\circ} \mathrm{C}$ and $22{ }^{\circ} \mathrm{C}$ were 41 and $121 \mathrm{KJ}$ oules $/ \mathrm{M}^{2}$ (240 and $700 \mathrm{in}-1 \mathrm{~b} / \mathrm{in}^{2}$ ), respectively (32). The $\mathrm{J}$ analyses assumed that the crack was subjected to quasi-static luading.

The $J$ analyses require the stress-strain curve of the material at the appropriate service temperature. In particular, this requires the Ramberg-Osgood (R-O) parameters for the stress-strain curve of the material. The values of $R-0$ parameters are given in Table 2 .

The procedure for determining the crack size at the initiation of crack extension for specified axial load is described next. The applied J-integral is calculated as a function of crack size for the specified load and tank car shell geometry. The applied $J$ is calculated using the solution given in section entitled Circumferential Throughwall Crack Under Axial Tension. A large number of crack lengths were postulated. The applied $J$ values are plotted against postulated crack lengths as shown in Figure 6. A line representing the material $J_{1}$ is next drawn on such a plot. The intersection of the applied $J$ curves with the $J$, line determines the critical crack size for the specified axial load. The procedure is the same for any other type of load or flaw geometry. The Ductile Fracture Handbook, Ref. 5, gives a sample problem and the step-by-step solution for the bending moment loading case.

\section{$\underline{\text { RESULTS }}$}

Figure 6 shows the calculated $J$ values for five axial loading cases that cover service, test, and design conditions. These results are for $-40{ }^{\circ} \mathrm{C}$ service temperature. As mentioned before, the calculations were performed for the AAR TC128 grade B normalized steel. The critical crack size is determined from Figure 6 by obtaining the intersection of $41 \mathrm{KJoules} / \mathrm{M}^{2}$ with the applied J 
curves. The critical crack lengths are summarized in Table 3 . The calculated $\mathrm{J}$ values for service temperature of $22{ }^{\circ} \mathrm{C}$ are shown in Figures 7 and 8 . At this temperature, the $J_{1}$ value was taken as $121 \mathrm{KJ}$ oules $/ \mathrm{M}^{2}(28)$. This is a conservative value since it represents $\mathrm{J}$ toughness at $-18{ }^{\circ} \mathrm{C}$. The critical crack size results are summarized in Table 3. These results are also plotted in Figure 9.

This figure can be used to determine the critical crack length for any load that is bounded by the loading considered herein.

\section{DISCUSSIONS, CONCLUSIONS, AND RECOMMENDATIONS}

Fracture mechanics analyses using the J-integral as fracture parameter were performed for two service temperatures of $-40^{\circ} \mathrm{C}$ and $22^{\circ} \mathrm{C}$ and five axial loading cases. The loading cases were: (1) coupler impact force, (2) test pressure, (3) start-to-discharge pressure, (4) burst pressure, and (5) vapor tight minimum pressure. Circumferential throughwall cracks in the tank car shell region were postulated to determine the critical crack size.

The analyses were based on the applied $\mathrm{J}$ reaching $\mathrm{J}_{1}$, the material toughness at crack extension. Material J-resistance ( $J-R)$ curves could have been used in fracture analyses, but these were not available. However, the $\mathrm{J}-\mathrm{R}$ curve data is relevant above NDT temperature. Consequently, the results for $-40{ }^{\circ} \mathrm{C}$ are accurate. When $J-R$ curve is used in the analysis, the critical crack size obtained is larger than those when $\mathrm{J}$ is used. Consequently, the results for $22^{\circ} \mathrm{C}$ are conservative. The $\mathrm{J}$ analyses assumed that the crack was subjected to quasistatic loading.

The analyses indicate that the critical crack lengths at $22{ }^{\circ} \mathrm{C}$ are larger by factors of 1.5 to 2 than those for $-40^{\circ} \mathrm{C}$. The critical crack lengths for discharge pressure were 17.1 and 29.2 inch at service temperatures of $-40{ }^{\circ} \mathrm{C}$ and $22^{\circ} \mathrm{C}$. These crack lengths are approximately 30 to 50 times the tank car shell wall thickness. The critical crack lengths for the coupler impact force are approximately 1.7 times larger than those for the discharge pressure. The critical crack length is determined to be the largest for the impact force case. The results also show that even at burst pressure small throughwall cracks (four times tank shell thickness) can be tolerated.

In a leak-before-break scenario, when a part-throughwall flaw extends throughthe-wall the resulting throughwall crack must be smaller than the critical throughwall crack length. While analyses for part-throughwall flaw were not performed, it can be argued that a propagating surface flaw having length-todepth ratio (aspect ratio) lass than 25 will produce leak-before-break at service temperatures of $-40{ }^{\circ} \mathrm{C}$.

It is recommended that service failure data should be examined to determine whether part throughwall flaws with aspect ratio greater than 25 can exist in the tank car shell region. Fracture mechanics analyses for part-throughwall flaws are recommended to determine the flaw shape and size that would produce leakbefore-break condition for the tank car. A safety margin should be applied on the predicted crack length to account for the variation in $\mathrm{J}$ toughness at the evaluation temperature. 
TABLE 1. Loads Used in Fracture Mechanics Analyses.

\begin{tabular}{|c|c|c|c|c|}
\hline Loading Category & $\begin{array}{l}\text { Pres } \\
\mathrm{MPa}\end{array}$ & $\begin{array}{l}\text { sure } \\
\text { (psi) }\end{array}$ & $\begin{array}{l}\text { Calcu } \\
\text { MN }\end{array}$ & $\begin{array}{l}\text { d Axial Load } \\
(1 \mathrm{~b} \cdot \mathrm{E} 6)\end{array}$ \\
\hline Impact force & $\ldots$ & $\ldots$ & 5.8 & 1.3 \\
\hline Test pressure & 2.3 & 340 & 14.3 & 3.2 \\
\hline Start-to-discharge pressure & 1.8 & 255 & 10.8 & 2.4 \\
\hline Burst pressure & 5.9 & 850 & 36.2 & 8.1 \\
\hline Vapor tight minimum pressure & 1.4 & 204 & 8.5 & 1.9 \\
\hline
\end{tabular}

TABLE 2. Material Stress-Strain Parameters

\begin{tabular}{lcc}
\hline & \multicolumn{3}{c}{ Temperature } \\
Parameter & $-40{ }^{\circ} \mathrm{C}$ & $2{ }^{\circ} \mathrm{C}$ \\
\hline$\alpha$ & 0.83 & 0.91 \\
$\mathrm{n}$ & 7.93 & 7.74 \\
$\sigma_{0} \mathrm{MPa}(\mathrm{ksi})$ & $488.5(70.9)$ & $446.5(64.8)$ \\
$\sigma_{f} \mathrm{MPa}(\mathrm{ksi})$ & $608.4(88.3)$ & $560.2(81.3)$ \\
$\mathrm{E} \mathrm{GPa}(\mathrm{ksi})$ & $206.7(30,000)$ & $206.7(30,000)$ \\
\hline
\end{tabular}

TABLE 3. Critical Crack Size for AAR TC128 Grade B Tank Car Shell, Normalized Steel.

\begin{tabular}{|c|c|c|c|c|}
\hline \multirow[t]{2}{*}{ Loading Category } & \multicolumn{2}{|c|}{$\begin{array}{l}\text { Critical Throughwall } \\
-40{ }^{\circ} \mathrm{C}\end{array}$} & \multirow{2}{*}{$\begin{array}{r}\text { Crack } \\
22 \\
\underline{\mathrm{cm}}\end{array}$} & \multirow{2}{*}{$\begin{array}{l}\text { Length } \\
{ }^{\circ} \mathrm{C} \\
\underline{\text { inch }}\end{array}$} \\
\hline & $\underline{\mathrm{cm}}$ & $\underline{\text { inch }}$ & & \\
\hline Impact force & 85.3 & 33.6 & 127.3 & 50.1 \\
\hline Test pressure & 31.5 & 12.4 & 55.9 & 22.0 \\
\hline Start-to-discharge pressure & 43.4 & 17.1 & 74.2 & 29.2 \\
\hline Burst pressure & 6.4 & 2.5 & 14.7 & 5.8 \\
\hline Vapor tight minimum pressure & 55.9 & 22.0 & 90.9 & 35.8 \\
\hline
\end{tabular}




\section{REFERENCES}

1. C. G. Interrante, G. E. Hicho, and D. E. Harne, "A Metallurgical Analysis of Five Steel Plates Taken From a Tank Car Accident Near Crescent City, Illinos," NBS Report 312.01/39, March 1972.

2. C. G. Interrante, G. E. Hicho, and D. E. Harne, "A Metallurgical Analysis of Eleven Steel Plates Taken From a Tank Car Accident Near Callao, Missouri," NBS Report 312.01/51, Sept. 1972.

3. C. G. Interrante, J. G. Early, and G. E. Hicho, "Analysis of Findings of Four Tank-Car Accident Reports," NBSIR 75-655, Report No. 5, Jan. 1975.

4. C. G. Interrante and G. E. Hicho, "Impact Properties of Steels Taken From Four Failed Tank Cars," NBSIR 75-656, Report No. 6, Jan. 1975.

5. A. Zahoor, Ductile Fracture Handbook. Vols. 1. 2 and 3, Electric Power Research Institute, 1989-91. EPRI NP-6301-D/N14.

6. V. Kumar,- M. D. Germar, W. W. Wilkening, W. R. Andrews, H. G. delorenzi, and D. F. Mowbray, "Advances in Elastic-Plastic Fracture Analysis," Electric Power Research Institute, Palo Alto, CA, August 1984. EPRI NP -3607 .

7. V. Kumar and M. D. German, "Elastic-Plastic Fracture Analysis of Throughwall and Surface Flaws in Cylinders," Electric Power Research Institute, Palo Alto, CA, January 1988. EPRI NP-5596.

8. A. Zahoor, "Closed Form Expressions for Fracture Mechanics Analysis of Cracked Pipes," ASME J. PVT, Vol. 107, 1985, pp. 203-205.

9. F. Delale and F. Erdogan, "Transverse Sheer effects in a Circumferentially Cracked Cylindrical Shell," Quarterly Applied Math, Vo1. 37, 1979, p. 239.

10. J. L. Sanders, Jr., "Circumferential Through-crack in a Cylindrical Shell Under Combined Bending and Tension," ASME J. Applied Mechanics, Vol. 50, 1983, p. 221.

11. M. E. Duncan-Faina and J. L. Sanders, Jr., "A Circumferential Crack in a Cylindrical Shell Under Tension," Intl. J. of Fracture Mechanics, Vol. 6, 1970, pp. 379-392.

12. "Standard Test Method for Determining J-R Curves," ASTM Method El 15287, Section 3, Annual Book of ASTM Standards, American Society for Testing and Materials, Philadelphia, PA, 1988.

13. P. C. Paris, H. Tada, A. Zahoor, and H. Ernst, "A Treatment of the Subject of Tearing Instability." Nuclear Regulatory Commission, Washington, DC, 1977. NUREG-0311; see also Elastic-Plastic Fracture, ASTM STP 668,1979 , pp. 5-36 and pp. 251-265. 
14. A. Zahoor, "Tearing Instability of Elastic-Plastic Crack Growth," D:SC. Dissertation, Washington University, St. Louis, August 1978.

15. A. Zahoor and M. F. Kanninen, "A Plastic Fracture Mechanics Prediction of Fracture Instability in a Circumferentially Cracked Pipe in Bending Part 1: J-integral Analysis," ASME J. Pressure Vessels Technology, Vol. 103, 1981, pp. $352-358$.

16. A. Zahoor and M. F. Kanninen, "A Plastic Fracture Instability Analysis of Wall Breakthrough in Circumferentially Cracked Pipe Subjected to Bending Loads," ASME J. Engineering Materials \& Technology, Vol. 103, 1981, pp. 194-200.

17. A. Zahoor and M. F. Kanninen, "Ductile Fracture of Circumferentially Cracked Pipes Subjected to Bending Loads," in Elastic-Plastic Fracture, ASTM STP 803, Vol. II, American Society for Testing and Materials, 1983, pp. $11-291-11-308$.

18. "Instability Predictions for Circumferentially Cracked Type-304 Stainless Steel Pipe Under Dynamic Loading" M. F. Kanninen, et al, Electric Power Research Institute, Palo Alto, CA, April 1982. EPRI NP-2347, Vols. 1 and 2 .

19. A. Zahoor and D. M. Norris, "Ductile Fracture of Circumferentially Cracked Type-304 Stainless Steel Pipes in Tension," ASME J. Pressure Vessels Technology, Vol. 106, 1984, pp. 399-404.

20. W. S. Pellini, "Introduction to AAR Guidelines for Fracture-Safe Design Involving Temperature-Transition Sensitive Structural Steels," Association of American Railroads, Report No. R-383, August 1979.

21. W. S. PelIini, "Guidelines for Fracture Mechanics Analysis of Pressure Tank Car Structural Integrity Factors," Association of American Railroads, Final Draft Report, March 1984.

22. C. I. Chang, M. Nakagaki, C. O. Griffis, and R. A. Masumara, "Piping Inelastic Fracture Analysis," NUREG/CR 1119, Nuclear Regulatory Commission, Washington, D.C., 1980.

23. "American Society of Mechanical Engineers Boiler and Pressure Vessel Code." 1989 Edition and Addenda, Section XI, Paragraph IWB-3650.

24. A. Zahoor, "New Crack Instability Results and Modification Factors for Type-304 Stainless Steel Base Metals and Shielded Metal Arc Welds," Presented to ASME Section XI Task Group on Piping Flaw Evaluation, Crystal City, VA, Novenber 1984.

25. "Evaluation of Flaws in Austenitic Steel Piping, "Prepared by the Section XI Task Group for Piping Flaw Evaluation, ASME Boiler and Pressure Vessel Code Committee, EPRI Report NP 4690-SR, April 1986; see also ASME J. Pressure Vessel Technology, Vol. 108, 1986, pp. 352-367. 
26. A. Zahoor, H. S. Mehta, S. Yukawa, R. M. Gamble, and S. Ranganath, "Flaw Evaluation Procedures and Standards for Ferritic Piping," Electric Power Research Institute, Palo Alto, CA, October 1986. EPRI NP-4824SP.

27. A. Zahoor, "Z-Factors and Revised Criteria for Evaluation of Flaws in Carbon Steel Piping," Presented to ASME Section XI Task Group on Piping Flaw Evaluation, Long Beach, CA, January 1987, see also IWB-3650, Section XI of ASME B\&PV Code, 1988 and EPRI NP-6045, October 1988.

28. A. Zahoor, "Experimental Verification of Z-Factor Flaw Evaluation Procedure,"Presented to ASME Section Xl Task. Group on Piping Flaw Evaluation, New Orleans, April 1987; see also, "EPRI Report: Evaluation of Flaws in Ferritic Piping," EPRI NP-6045, 1988.

29. "Evaluation of Flaws in Ferritic Piping," Report Prepared by Novetech Corporation for Electric Power Research Institute, Palo Alto, CA, October 1988. EPRI NP-6045.

30. A. Zahoor, Unpublished work, 1991.

31. Manual of Standards and Recommended Practices. Section C-Part I11. Specifications for Tank Car, Specification M-1002, September 1,1985.

32. G. E. Hicho and D. E. Harne, "Mechanical Properties and Fracture Toughness of AAR TC128 grade B Steel in the Normalized, and Stress Relieved Conditions," National Institute of Standards and Technology, NISTIR 4660, Report No. 24, September 1991. 

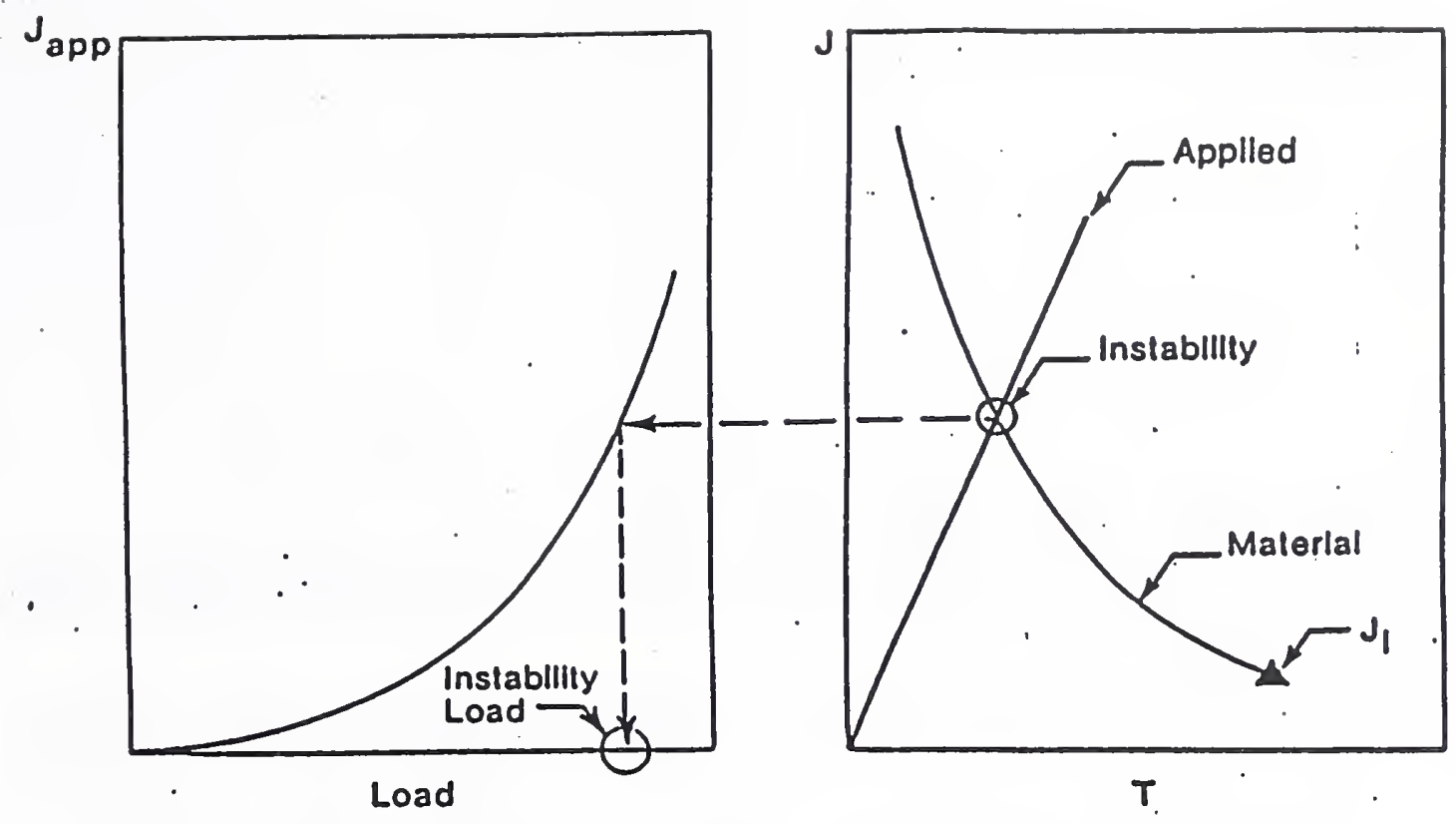

Figure 1. Illustrations of the J-T Procedure.

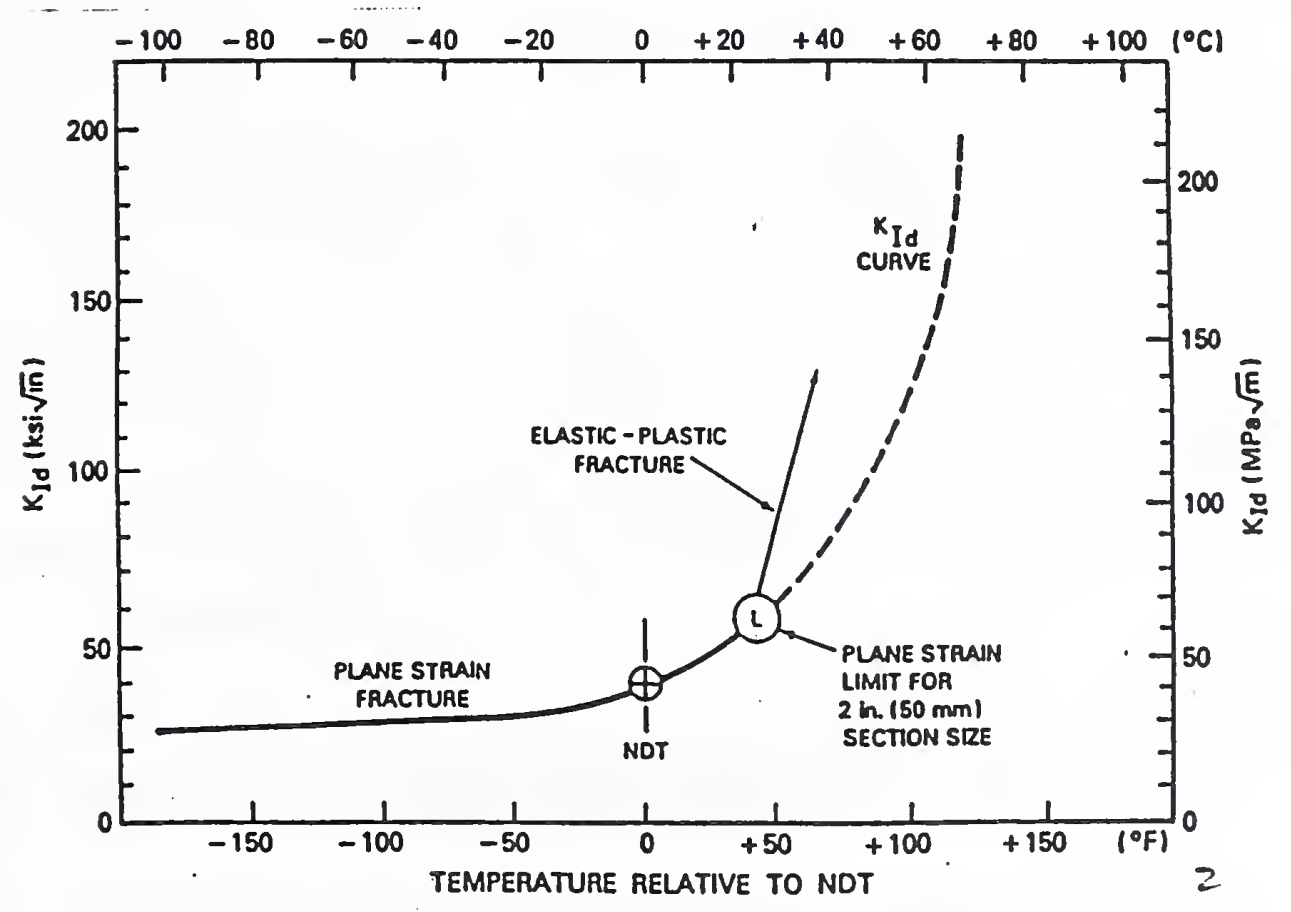

Figure 2. Illustration Showing a $\mathrm{K}_{\mathrm{Id}}$ Curve. 


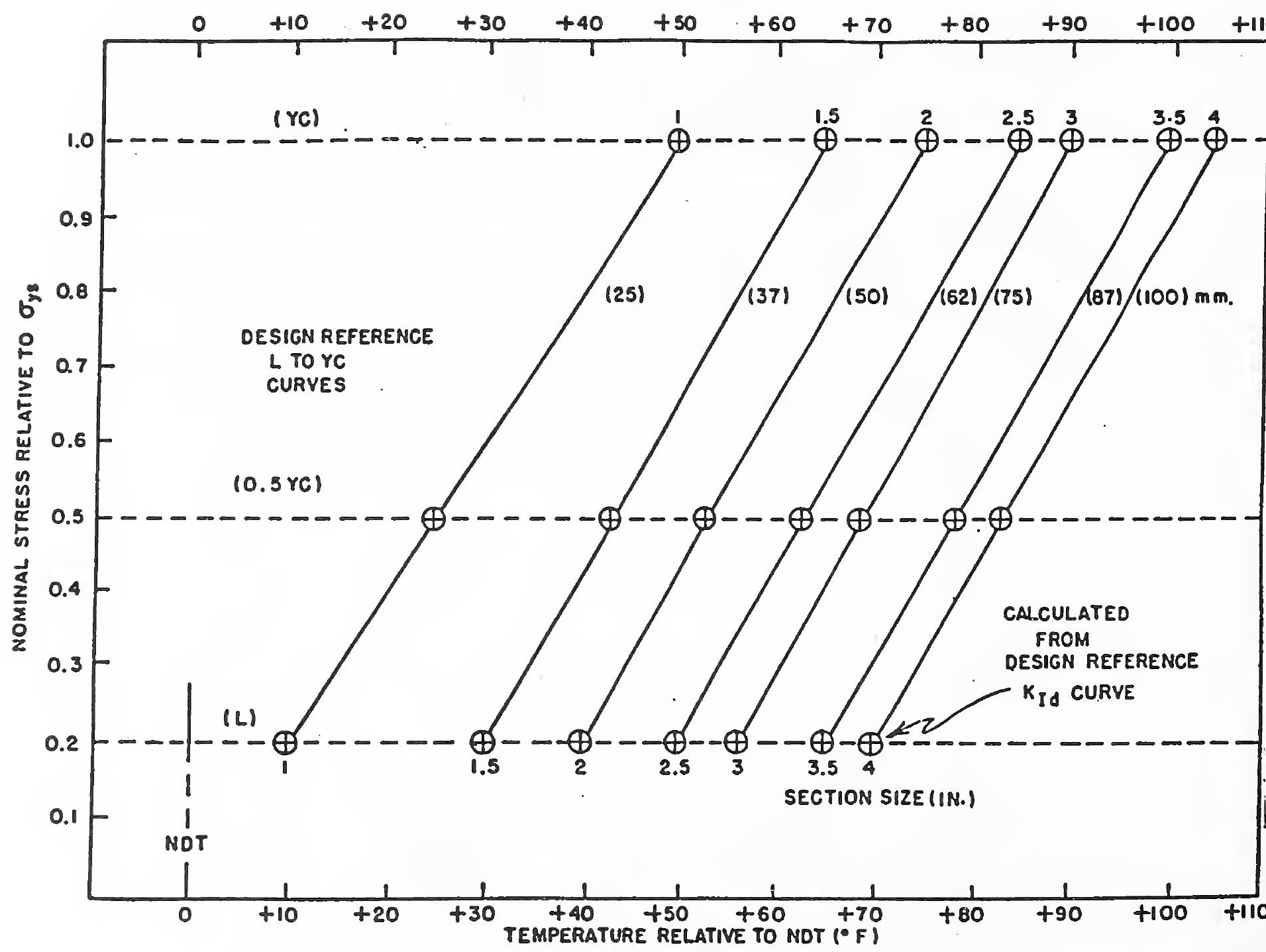

Figure 3. AAR Design Reference Graphs for L to YC Temperature Transition Curves. 


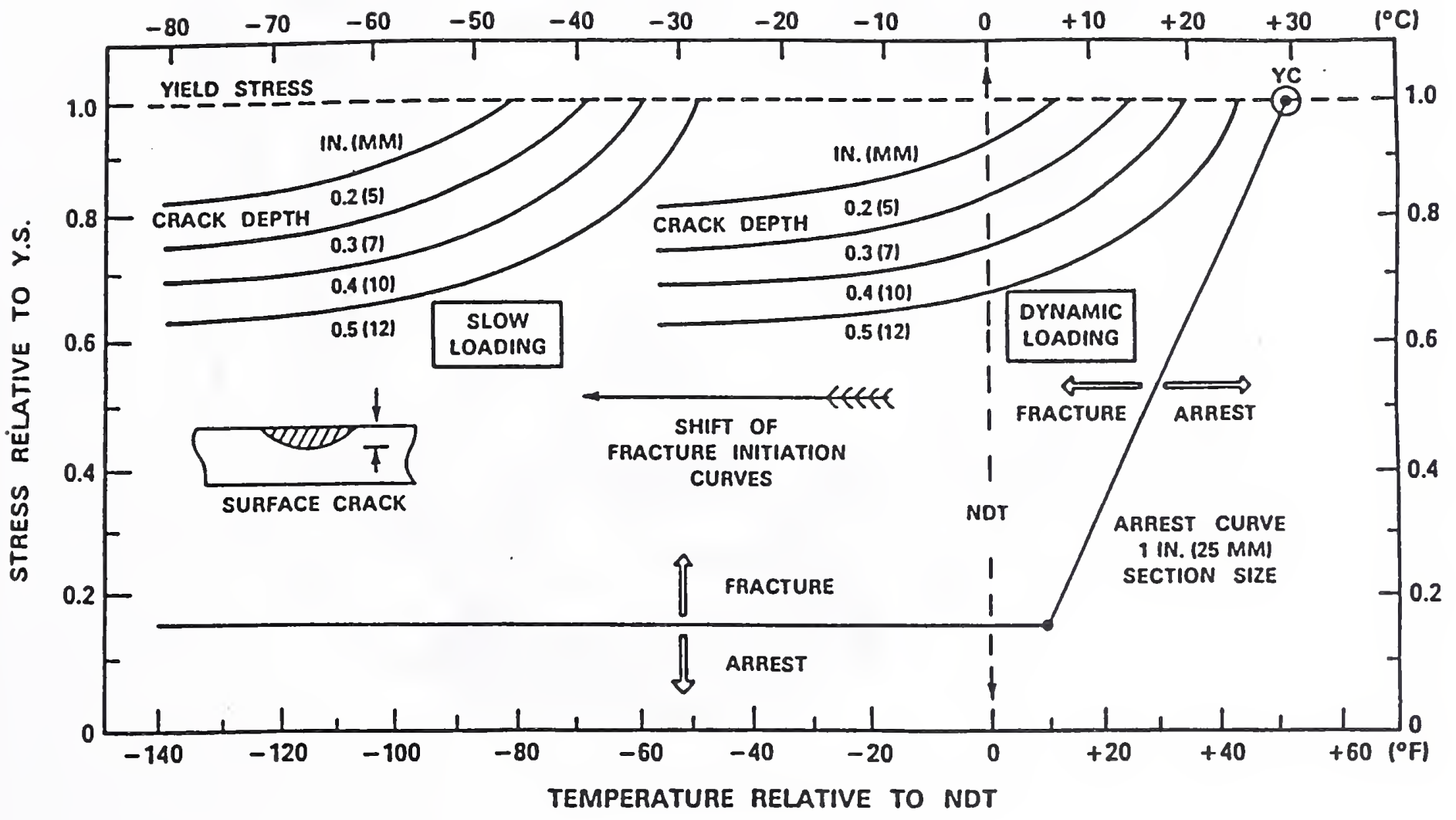

Figure 4. Illustration of AAR Fracture Analysis Graph. 


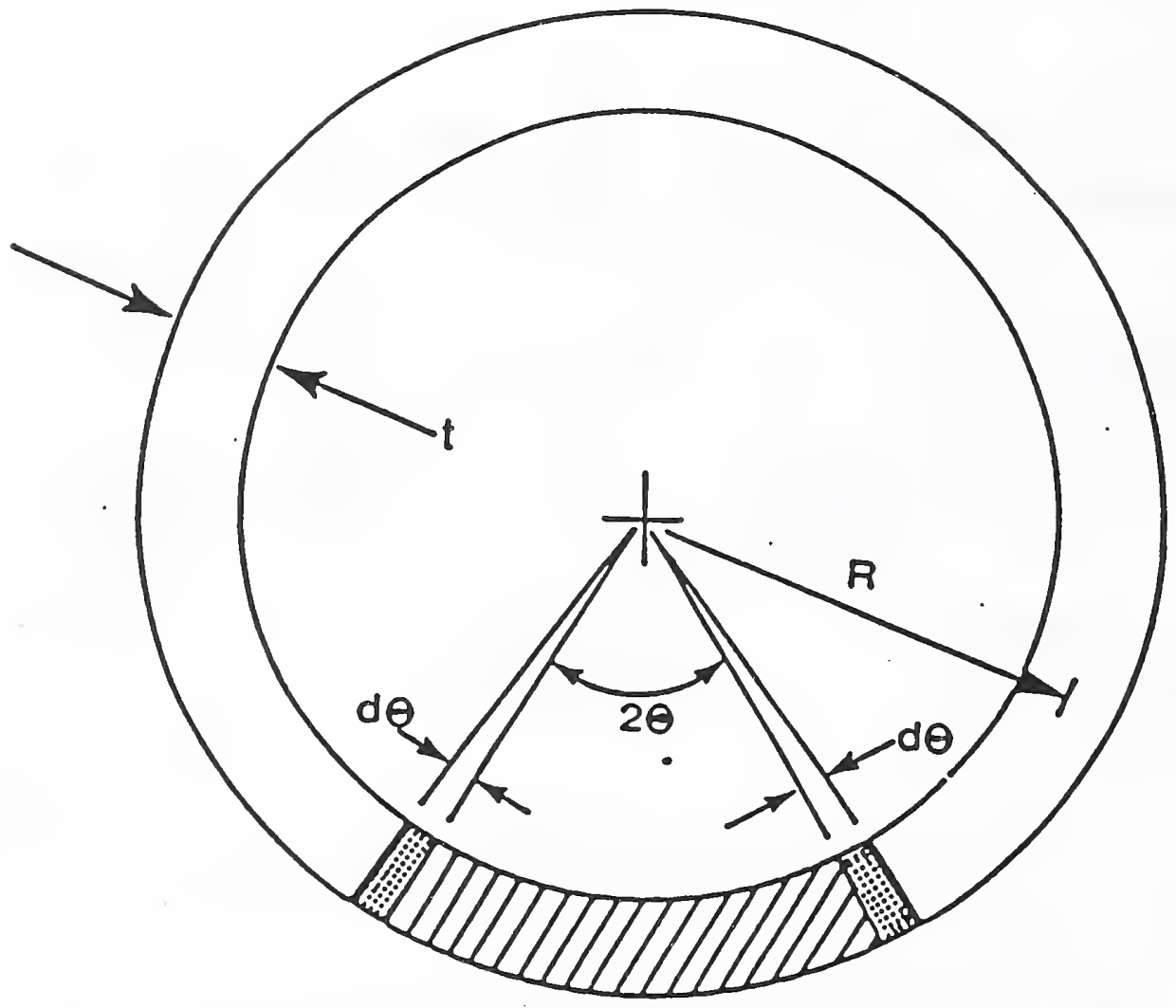

Figure 5. Illustration of A Circumferential Throughwall Crack and Angular Relationships. 


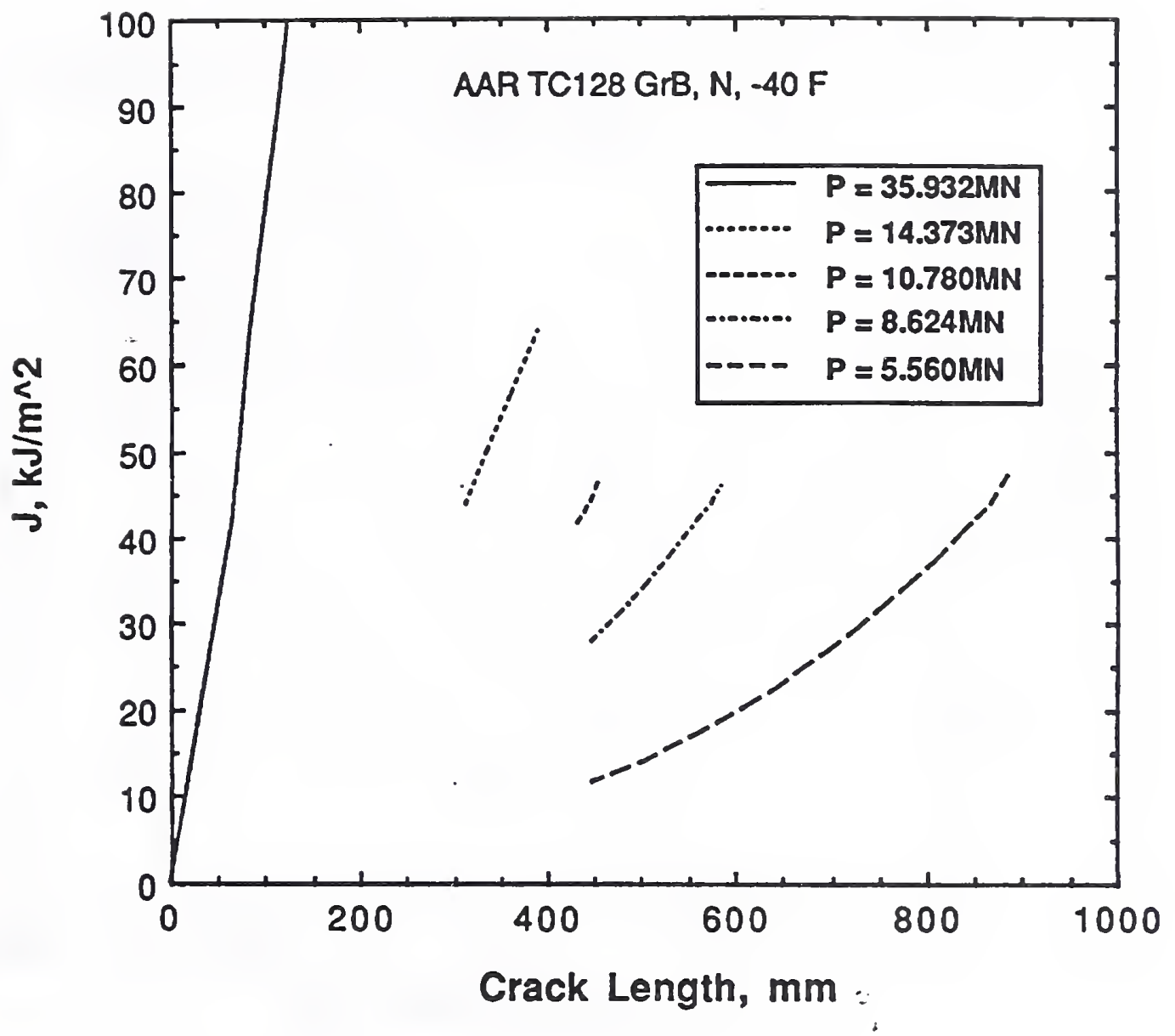

Figure 6. Applied J, at $-40 \mathrm{C}$, Versus Crack Length for Several Axial Loading Cases. 


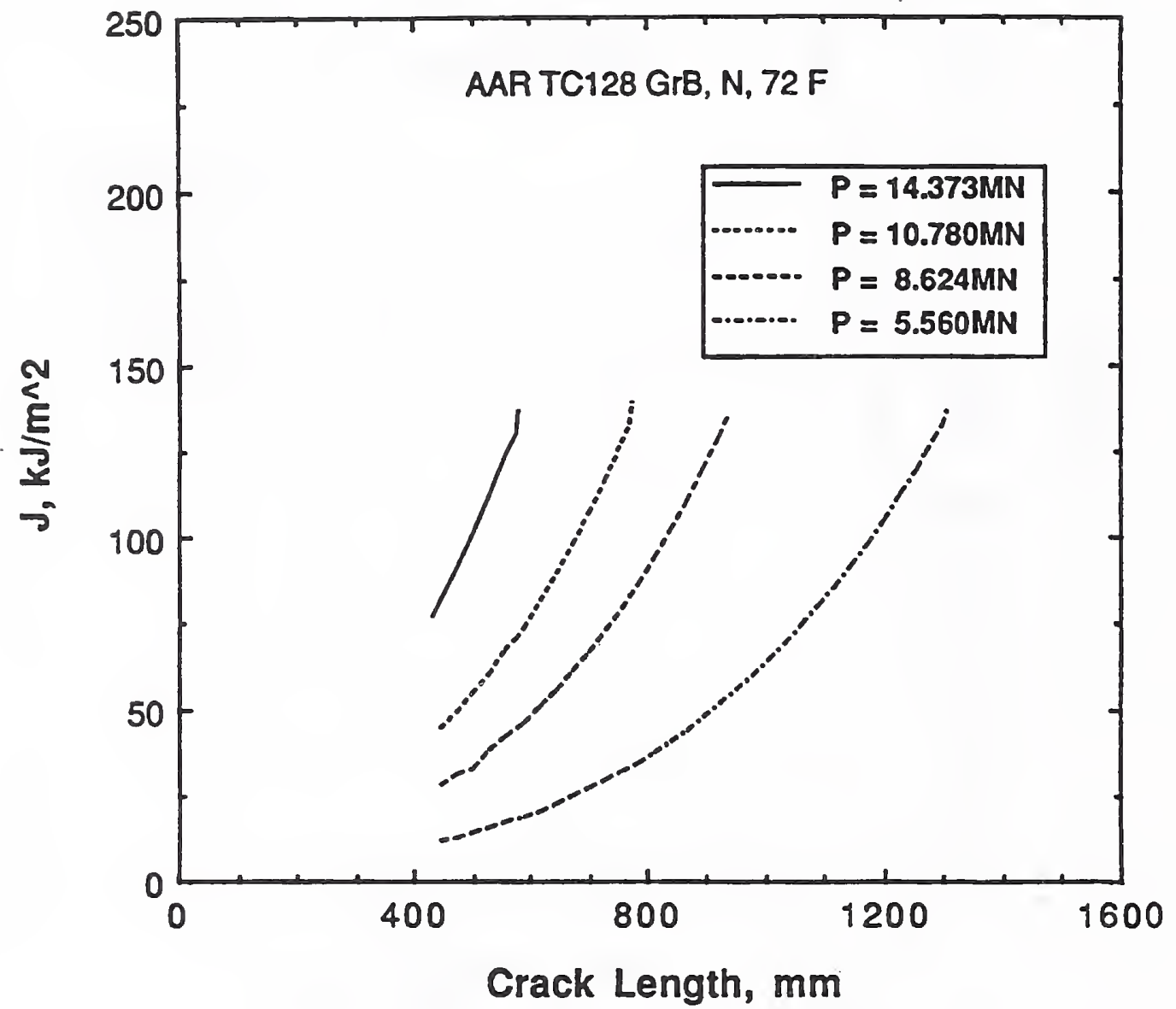

Figure 7. Applied J, at $22 \mathrm{C}$, Versus Crack Length for Several Axial Loading Cases. 


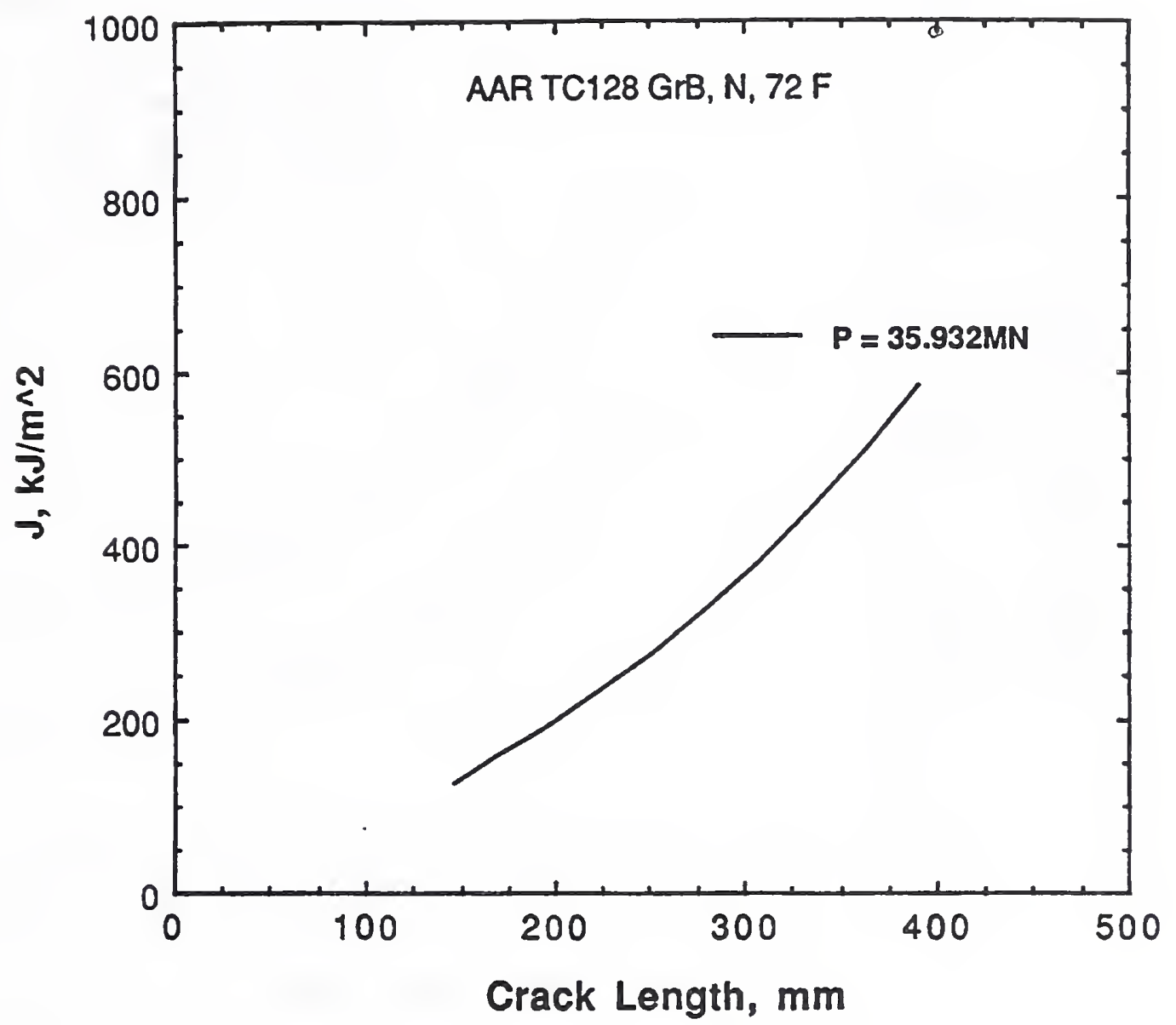

Figure 8. Applied $J$, at $22 \mathrm{C}$, Versus Crack Length for $P=35.932 \mathrm{MN}$ $(8,077,820$ 1b). 


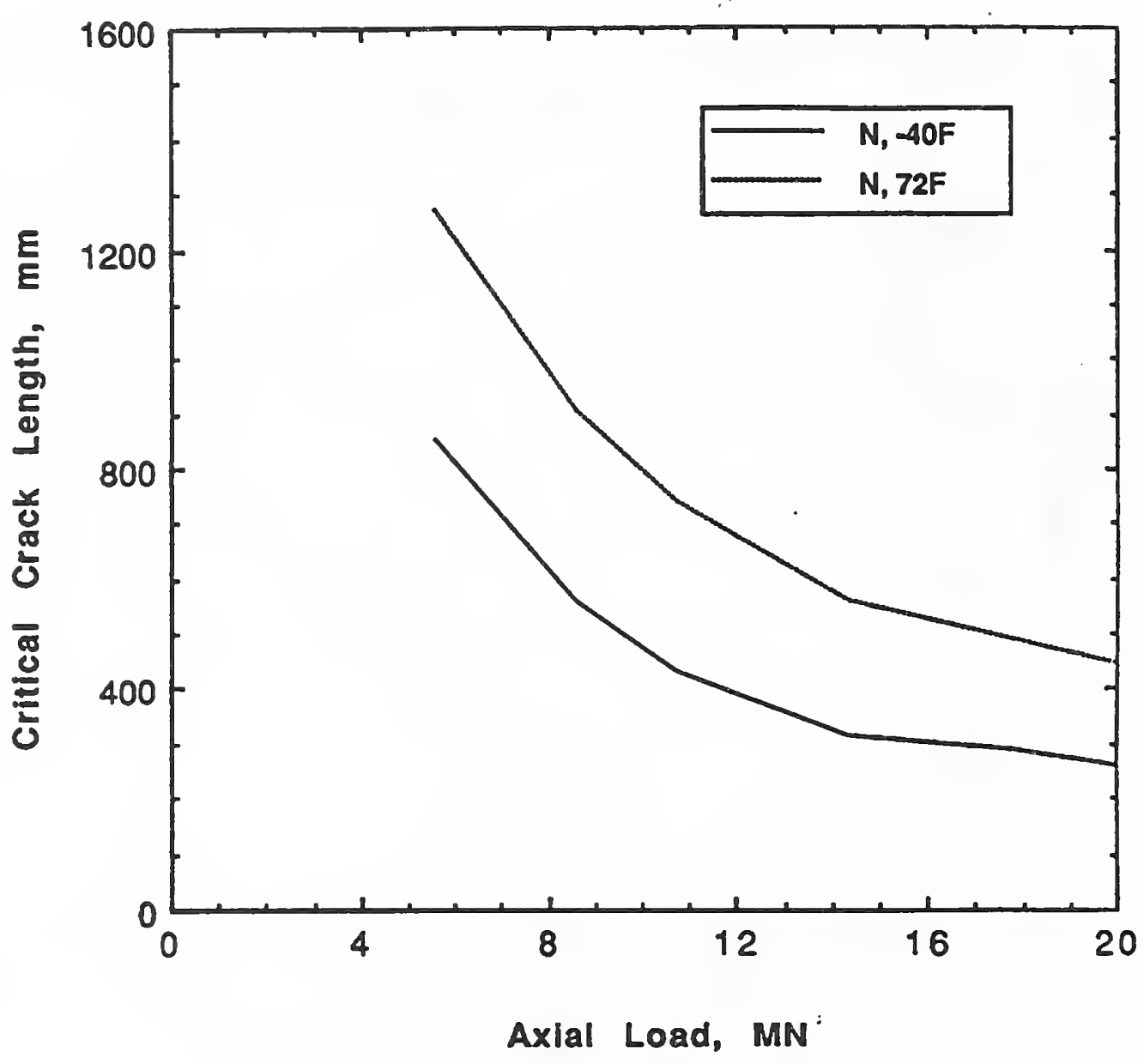

Figure 9. Critical Throughwall Crack Length versus load for normalized AAR TC128 grade B Tank Car Shell Steel. The Curves are for a Circumferential Crack in the Shell Plate. 

